International Journal of Linguistics, Literature and Translation

ISSN: 2617-0299 (Online); ISSN: 2708-0099 (Print)

DOI: $10.32996 /$ ijllt

Journal Homepage: www.al-kindipublisher.com/index.php/ijltt

IJLLT

\title{
Barriers to Teaching English Productive Skills in Online Classroom: A Study at the Private Universities in Bangladesh
}

\author{
Chowdhury Adiba Zahin ${ }^{1} \square$ and Most. Mushfeka Zannat ${ }^{2}$ \\ ${ }^{12}$ Department of English, Bangladesh Army University of Science and Technology Saidpur, Rangpur- 5310, Bangladesh \\ $\square$ Corresponding Author: Chowdhury Adiba Zahin, E-mail: adiba.zahin73@gmail.com
}

ARTICLE INFORMATION
Received: 10 October 2021
Accepted: 20 November 2021
Published: 27 December 2021
DoI: $10.32996 /$ ijllt.2021.4.12.19

\section{KEYWORDS}

Barriers, communication, feedback, motivation, productive skills

\section{ABSTRACT}

This paper aims at investigating the barriers to teaching productive skills in English in an online platform in the private universities of Bangladesh and attempt to find out the solutions regarding this issue, focusing mainly on the private universities outside Dhaka. Since English is a significant communication tool, it is indispensable to speak and write correctly in English. However, the students have often struggled to speak fluently and write well. As a result, it is necessary to find the main barriers to teaching these two productive skills. In addition, due to the COVID-19, teaching and learning have shifted from real life to virtual classrooms. The existing problems underlying teaching English productive skills have been more crucial in a virtual platform. Therefore, through questionnaire for teachers and classroom observation data was collected from six private universities outside Dhaka, and it has been found that the problems lie mainly in the inability to change the teaching methods and techniques according to the need of an online classroom alongside network issues interrupting effective communication and time management. In an online classroom, the teachers cannot involve the students in pair and group work for speaking and writing activities and provide feedback. Based on the study's findings, it is recommended that more speaking and writing practice in the classroom, interesting visual materials, constant motivation, feedback, and teachers' training were essential to overcome the challenges faced by the teachers for teaching productive skills in English in an online classroom.

\section{Introduction}

English has been taught as a mandatory subject in our country for a long period, covering four major phases of education: primary, secondary, higher secondary and tertiary education. Speaking and writing are considered the most important skills students require to enhance their personal development and academic success (Mukulu et al., 2006). According to Nunan (1991), "writing is an extremely complex cognitive activity in which the writer is required to demonstrate control of variables simultaneously. These include control of contents, format, sentence structure, vocabulary, spelling, and letter formation at the sentence level. Beyond the sentence, the writer must be able to structure and integrate information into a cohesive and coherent paragraph and text." (1991). In the academic context, students are required to produce specific writing genres such as essays, summaries and reports (DudleyEvans, 2001). According to Tangpermpoon (2008), writing is the most difficult skill among the other language skills because it needs the writers to have a great deal of lexical and syntactic knowledge as well as principles of an organization in L2. Hence, it is evident that to develop writing efficiency in English; the students must have good grammatical knowledge and the ability to form ideas and organize them properly. Speaking is another crucial productive skill of a language. McDonough and Shaw (1993) said that speaking is a skill that enables us to produce utterances while communicating; speaking is desire and purpose-driven. In the past, the main focus of teaching productive skills in English as a second language or foreign language followed the grammartranslation method. In this case, emphasis was given to teaching grammar, but communicative fluency was totally ignored. Though the era of the communicative approach has headed towards the post method era, reality has a different picture. Students have less exposure to real-life communication in the tertiary level of Bangladesh. Their fondness for the L1 refrains them from speaking in English even in the language classroom, which also results in poor writing ability. Moreover, there is no proper evaluation of students' oral skills, and no individual attention is given. It is unfortunate to state that most of the students cannot speak English

Copyright: (c) 2021 the Author(s). This article is an open access article distributed under the terms and conditions of the Creative Commons Attribution (CC-BY) 4.0 license (https://creativecommons.org/licenses/by/4.0/). Published by Al-Kindi Centre for Research and Development, London, United Kingdom. 
fluently and have less confidence in speaking even in front of their friends. If we want to make our students communicatively competent in English, it is important for the teachers to enhance their speaking and writing skills. It has been observed and found that several factors, i.e., absence of appropriate course materials, effective teaching methods and techniques, large classes, focus only on grammar-based teaching, lack of proper assessment and evaluation, teachers' unwillingness in providing feedback hinders the development of productive skills. During the pandemic, when the mode of education faced a drastic shift from offline to online teaching and learning, teaching speaking and writing in an online platform became more challenging as the problems of network, lack of teachers' training, insufficient time allocation for the class, inability to make the students participate in different activities etc. added to the existing barriers to effective teaching. In this paper, the researchers will attempt to find the barriers to teaching productive skills in an online platform at the tertiary level of Bangladesh collecting data from private universities throughout the country, especially the ones outside Dhaka.

Teaching speaking and academic writing at the tertiary level is still peripheral and neglected in Bangladesh though these are the most crucial language skills. The ability to write appropriate English and speak fluently is considered to be a major part of communicative competence among students at all levels of the education system. However, learning to master productive skills is a problem students face at every level. Teaching productive skills has always been difficult for the teachers, and it has been more difficult in an online class as the students are not communicating face to face with their teachers. In order to provide possible solutions to the problems faced by the teachers in the successful implementation of different teaching methods for speaking and writing that facilitates their learning, the researchers have made an attempt to identify the major barriers to their effective teaching.

\subsection{Research Objectives}

1. To identify various challenges that English teachers have faced while teaching productive skills in the online classroom.

2. To examine the student's motivation, attitude and adaptability in learning speaking and writing skills in an online classroom.

3. To investigate problems teachers' face in involving the students in creative writing.

4. To identify the hurdles faced by the teachers to involve the students in public speaking due to the lack of confidence in students.

\subsection{Research Questions}

1. What are the major barriers to teaching productive skills in an online classroom?

2. Do the students have a positive attitude in adapting to online learning?

3. Are the students motivated enough to speak and write spontaneously in an online classroom?

4. What are the factors that prevent teachers from engaging students in creative writing?

5. Why do the teachers face difficulty in involving the students to speak individually or in a group in an online classroom?

6. What are the recommendations to overcome the barriers in teaching productive skills in an online classroom?

\subsection{Significance of the study}

The central aim of the study is to explore the real scenario of teaching speaking and writing virtually at the tertiary level in Bangladesh especially focusing on the private universities and finding the barriers the teachers have faced while teaching in an online classroom. A number of research works have already been conducted on teaching and learning productive skills to EFL learners. However, the researches were mainly on personal teaching and learning. The present study carries significance because it will give us noteworthy perceptions about the different teaching, speaking, and writing problems in an online platform at the tertiary level during this pandemic. The study has immense prospects to offer teachers key insights about modifying different techniques and adapting updated methods for teaching EFL writing and speaking in virtual classrooms. Furthermore, teachers and learners will get a chance to explore the barriers that are common to all the teachers. Moreover, the findings of this study would serve as a basis for guiding the EFL teachers to adopt teaching strategies that will develop the learning of speaking and writing skills among students. Then, the study would enable curriculum designers and textbook writers to identify the limitations of the previous curriculum unfit for teaching virtually and create new materials that will be appropriate for teaching students online.

\section{Literature Review}

Since speaking is a dynamic process that is difficult to separate from listening in many ways, Nunan (1989) has mentioned that successful oral communicators should also develop 'conversational listening skills'. Moreover, Widdowson has mentioned the reciprocal exchange pattern of oral communication and considered that "What is said is dependent on an understanding of what else has been said in the interaction." (Widdowson, 1978, p. 58). Therefore, those learning oral communication skills should be exposed to these patterns and instructed to practice accordingly.

According to Nunan (1989), teachers can take either a bottom-up or top-down approach to teaching speaking skills. The bottomup view suggests that learners move from mastery of the smallest units of language, i.e. meaningful individual sounds, and move 
through the mastery of larger components of words and sentences to discourse (Nunan, 1989). On the contrary, the top-down approach suggests that learners start working from the larger elements and gradually goes to the smaller ones (Nunan, 1989). These views are further contrasted by Hatch (1978), whose point of view on bottom-up and top-down approaches focuses on learning the structure of conversation, i.e. how to use structures to build up sentences and form discourse and then interacting in real-life situations and vice versa. However, Ur (1991) emphasized that the participation of the students in classroom activities and motivation from the teachers are the reasons behind the success of any approaches to teaching speaking.

According to Hartfiel, Hughey, Wormuth, \& Jacobs (1985), good writing has to consider some aspects of writing; grammar, vocabulary, mechanics, content, and organization and Richard (1990) mentioned that learning to write either in the first or second language is one of the difficult tasks a learner encounter.

Few researchers have pointed out the responsibilities of teachers in teaching different skills. Kellogg (1999) focused mainly on the role of teachers in motivating the students into practising writing tasks, and the teachers should explore students and motivate them. Besides, the teachers should plan significant writing tasks by considering the students" level of motivation. Brown (2000) has a similar opinion to Kellogg, where he points out the role of the teachers as facilitators. He believes that the teacher's role has to be a facilitator (one who facilitates learning) and coach, not an authoritative arbiter. As a facilitator, the teacher offers guidance in helping students engage in the thinking process of composing but, in a spirit of respect for student opinion, must not impose his or her thoughts on student writing. Myles (2002) favoured the argument of Kellogg further, where he pointed to the fact that teachers should encourage the students to read academic texts and other works to enhance their academic writing. According to him, if the students are motivated to read books on L2, they will develop a positive attitude towards the language, boosting their confidence. Hence their writing will develop.

In addition, Jarvis (2005) mentioned the role of the feedback given by the teachers as positive reinforcement on the students. He suggested that teachers give positive remarks in their exercise books or verbally to inspire the students to use the target language. Shaywitz (2003), as cited by Farooqui and Majid (2007), believed that teachers should be aware of the different learning styles of the students. According to Shaywitz, a low achieving student in writing may not be equally a low achiever in learning other language skills. (Farooqui, 2007; Majid, 2007). Teachers should help the students to identify their own strengths and weaknesses. The teachers may face greater challenges in a mixed-ability classroom.

In a mixed ability class, the stronger students feel held back, and weaker students pressurized, and the teachers feel stressed. As a result, naturally, a teacher has to apply different strategies to adjust the lesson plans to fit the learning needs of all the individual students. According to Hess, a teacher should maintain a good bonding and communicate more in a mixed ability classroom. They need to make the students perform individually to boost their confidence. In addition, Basu and Barman (2013) suggested that the teacher should analyze the need, learning style and strategies, strengths, weaknesses and motivation of the students to teach effectively in a mixed ability classroom where effective communication can be a barrier. (Basu and Barman 2013; p-172-173) They recommended that the solution of mixed ability classroom is to have an open discussion between the students and their teacher. The use of pair work is necessary to involve all the class members. Pair work promotes cooperation in the classroom and makes it a more relaxed and friendly place. The students learn to share responsibility and learn through cooperation (Harmer, 2003: p, 116). According to Nunan, Group work activities bring forth various qualities such as tolerance, team spirit, giving and taking, establishing a direction on learning, developing imaginative and creative thinking, developing a critical and informed mind. Teachers are aware of the kind of grouping, size, layout of furniture, and seating arrangement. (Nunan: 1991).

\section{Methodology}

The current research is conducted to find out the teachers' barriers to teaching productive skills in online classrooms.

\subsection{Sampling}

This study collected data through questionnaires, observation, and document analysis. The questionnaire helped to address more specific issues. Each question was followed by probes designed to obtain more detailed responses. Consequently, the researcher has collected data from the teachers of different private universities, mostly outside Dhaka city. Questionnaire served to 20 teachers of English department from 6 private universities. The questionnaire result has been discussed in the findings and discussion parts. The respondents are randomly selected from six universities, of which three are controlled private universities and the other three private universities from different corners of the country. The universities were Bangladesh Army University of Science and Technology, Bangladesh Army International University of Science and Technology, Bangladesh Army University of Engineering and Technology, Pundra University of Science and Technology, Varendra University, Chittagang Independent University. This research follows Random sampling.

\subsection{Instrumentation}

The study will be conducted among the teachers who have experience teaching productive skills online from different private universities outside Dhaka city. The study uses the descriptive approach utilizing qualitative methods such as observational studies 
and questionnaires with existing information available in the respective field. The researchers have also collected data from previously published journal articles. A five-point Likert scale was used to identify the opinion of the participants. The ranking criteria were as follows:

\begin{tabular}{|l|l|}
\hline $\begin{array}{l}\text { Rate of } \\
\text { opinion }\end{array}$ & Interpretation of the scale \\
\hline 5 & Strongly agree \\
\hline 4 & Agree \\
\hline 3 & Neutral \\
\hline 2 & Disagree \\
\hline 1 & Strongly disagree \\
\hline
\end{tabular}

The participants gave detailed reasons for each problem and identified the problem ranking in their opinion. Most of the questions were close-ended. A set of questionnaires were prepared.

\subsection{Data collection}

The data for the research was collected from both primary and secondary sources. Primary data is collected directly from the teachers of private universities. The researchers enjoyed both participating and observing. The researchers go through different literary articles, critical compositions, and websites to find relevant materials that are considered secondary data sources. The researchers actively observe online classes in which productive skills are taught during the study. Questionnaires are also proved to be supportive of the study.

\begin{tabular}{|c|c|c|c|c|c|c|}
\hline SI. & Question & $\begin{array}{l}\text { Strongly } \\
\text { Agree }\end{array}$ & Agree & Neutral & Disagree & $\begin{array}{l}\text { Strongly } \\
\text { Disagree }\end{array}$ \\
\hline 1. & $\begin{array}{l}\text { Do you think effective communication } \\
\text { is possible in an online classroom? }\end{array}$ & - & $13 \%$ & - & $39 \%$ & $48 \%$ \\
\hline 2. & $\begin{array}{l}\text { Is the time allotted for speaking and } \\
\text { writing activities sufficient? }\end{array}$ & $9 \%$ & $24 \%$ & $5 \%$ & $37 \%$ & $25 \%$ \\
\hline 3. & $\begin{array}{l}\text { Is there enough training for teachers } \\
\text { to conduct online classes? }\end{array}$ & $8 \%$ & $15 \%$ & $6 \%$ & $46 \%$ & $25 \%$ \\
\hline 4. & $\begin{array}{l}\text { Do you think it's important to adopt } \\
\text { innovative teaching techniques to } \\
\text { improve the speaking and writing skills } \\
\text { of the students? }\end{array}$ & $23 \%$ & $52 \%$ & $10 \%$ & $5 \%$ & - \\
\hline 5. & $\begin{array}{l}\text { Is it possible to indulge students in } \\
\text { interactive pair and group work to } \\
\text { develop speaking skills in an online } \\
\text { classroom? }\end{array}$ & - & $22 \%$ & $6 \%$ & $40 \%$ & $32 \%$ \\
\hline 6. & $\begin{array}{l}\text { Do you think teaching productive skills } \\
\text { are hindered due to the } \\
\text { inattentiveness of the students in an } \\
\text { online platform? }\end{array}$ & $35 \%$ & $45 \%$ & $10 \%$ & $10 \%$ & - \\
\hline
\end{tabular}




\begin{tabular}{|l|l|l|l|l|l|l|}
\hline 7. & $\begin{array}{l}\text { Do you agree online class is more } \\
\text { effective than in-person class for } \\
\text { teaching productive skills? }\end{array}$ & - & - & - & $55 \%$ & $45 \%$ \\
\hline 8. & $\begin{array}{l}\text { Do you think online class decreases } \\
\text { students confidence to participate } \\
\text { actively in the classroom? }\end{array}$ & $10 \%$ & $39 \%$ & $05 \%$ & $37 \%$ & $09 \%$ \\
\hline 9. & $\begin{array}{l}\text { Do you think students lose their } \\
\text { motivation to respond and learn due } \\
\text { to the lack of face-to-face interaction } \\
\text { in an online classroom? }\end{array}$ & $45 \%$ & $50 \%$ & - & $5 \%$ & - \\
\hline 10. & $\begin{array}{l}\text { Do you think a large size classroom } \\
\text { makes it more difficult for teachers to } \\
\text { give feedback? }\end{array}$ & $45 \%$ & $37 \%$ & $4 \%$ & $14 \%$ & - \\
\hline 11. & $\begin{array}{l}\text { Do you think online class helps } \\
\text { improve students' ability in speaking } \\
\text { and writing? }\end{array}$ & - & $10 \%$ & $15 \%$ & $40 \%$ & $35 \%$ \\
\hline
\end{tabular}

\section{Findings and analysis}

This section presents and interprets the primary data collected from the respondents from the given setting in the form of a table. The study mainly focuses on finding out whether productive skills in virtual classes are effective, whether the courses are appropriately designed in terms of methodologies and materials, and the problems encountered both by the teachers while teaching and by the learners while learning productive skills online. Recurrent themes and major barriers to teaching productive skills in the online classroom were identified and comprised under two main categories: obstacles faced by teachers while teaching productive skills online and the reasons for the problems, and teachers' perceptions of students' problems faced in an online classroom.

Communication is crucial for teaching productive skills that become challenging in an online class. From the teacher's questionnaire findings, $48 \%$ of teachers strongly disagree with the statement that effective communication is possible in an online classroom. That is why $39 \%$ of them also disagree with it. Only $13 \%$ of teachers thought that effective communication could be possible in an online classroom.

Collected data shows that teachers disagree with the time allocation for speaking and writing activities and offered training for conducting an online class with $37 \%$ and $46 \%$, respectively. Teaching productive skills, namely, speaking and writing, demand a lot of practice or activities that seem inconvenient due to the limited time allotted for an online class. On the contrary, $24 \%$ and $15 \%$ of teachers agree with the time allocation for class and their training. Around $40 \%$ of teachers disagree, and $32 \%$ of them strongly disagree with the statement that it is possible to indulge students in interactive pair or group work to develop speaking skills in an online classroom. In contrast, only $22 \%$ of teachers agree with this statement.

The findings of teachers' perception on the effectiveness of online classes show that $55 \%$ of them strongly disagree, and $45 \%$ disagree with the statement that in-person class is more effective than online class. At the same time, $45 \%$ of teachers strongly agree that students lost their motivation to participate and learn in an online classroom due to a lack of face-to-face classes. Whereas $50 \%$ of them also agree with this.

More than half the proportion of teachers that are $52 \%$ and $23 \%$ agree and strongly agree respectively indicated that adapting innovative techniques is a must for improving student's speaking and writing ability in an online classroom. To conduct online classes, teachers need to be very innovative in their approach to teaching and their adaptation of materials.

When asked whether a large classroom makes it more difficult to give feedback while teaching online, $45 \%$ of teachers strongly agree while $37 \%$ agree, and only $14 \%$ disagree. In an online classroom, some of the students just joined class but did not pay attention to class at all. That is why around $45 \%$ of teachers agree that teaching productive skills is hindered due to students' inattentiveness, while $35 \%$ strongly agree with it. In contrast, only $10 \%$ remained undecided.

A total of $40 \%$ and $35 \%$ of teachers disagrees and strongly disagree, respectively, with the statement that online classroom helps to improve students' ability in speaking and writing. To improve skills, one needs to participate, whereas, in an online class, students get little chance to participate in speaking and writing activities and proper feedback from teachers. That is why it decreases students' confidence to actively participate in an online class. Around $39 \%$ of teachers agree, and $10 \%$ strongly agree with the 
statement mentioned above. On the other hand, only $10 \%$ agree, and the rest remain undecided. Whereas $37 \%$ and $9 \%$ disagree and strongly disagree, respectively, with the statement.

Most of the teachers perceived students' problems while attending the online class. Their demotivation, lack of confidence, low self-esteem, and inattentiveness make productive skills classless effective. To overcome all the problems, most teachers thought to improvise their teaching techniques and materials. At the same time, they tend to indulge students in classroom activities more and more.

\section{Discussion}

Through cross-checking the teachers' interviews and questionnaires, it is evident that the major barriers of teaching productive skills in an online classroom are insufficient time allocation, network issues, negative attitudes and demotivation of students in adapting online learning, inability to involve students in creative writing and speaking activities due to large size class, anxiety and low confidence of students, lack of feedback from teachers and no proper training for conducting online classes. Teaching speaking and writing in an online classroom seems more difficult than an in-person class since indulging the students in speaking and writing activities, namely role play, drill, presentation, brainstorming, drafting, etc., has become more challenging in an online classroom. In teaching speaking, the students must have the urge to communicate with their peers as most of the speaking activities are related to pair work and group work. Teachers plan to conduct their speaking classroom based on pair and group work in an in-person classroom. That seems a bit difficult to implement in an online classroom. Since interaction is not easy to compare to an in-person classroom, students are connected through the internet, where they may or may not turn on their video in an online classroom. So, discussion among the students is not convenient in such a setting. As a result, teachers may indulge students in group work where they give students home tasks to communicate among themselves in a group to prepare on a topic and just perform it in the class. Nevertheless, instant group discussion and performance is a bit chaotic in an online setting where students cannot interact with each other freely all at once. Hence communication and interaction among students in an online classroom hindered their performance as they feel demotivated toward interactive classrooms where they need to perform in pairs or groups. Additionally, students lost their confidence to perform together due to the absence of pair or group work. Teaching productive skills in an online classroom is challenging. In addition, demotivated students and students with less confidence are more challenging for teachers to teach productive skills.

For effective speaking practice, students need to participate in controlled and guided activities like a drill, role play, discussion, simulation, presentation etc. However, in an online classroom, ensuring each student's participation is troublesome due to the scarcity of time, network problems, and large classes. But the teachers must try to overcome such hurdles and create a comfortable environment for students so that they feel encouraged to communicate with teachers as well as fellow students.

Assuring the participation of the students in writing activities is similarly challenging in an online classroom. Creative writing should be encouraged, as it engages the students to form and develop their ideas and enhance their writing ability by organizing these ideas with correct grammatical sentences. A typical creative writing activity includes engaging students individually, in pairs or groups, to come up with ideas, discuss their ideas in front of the class, and finally give their ideas a written form with correct grammar and organization. Nevertheless, these steps cannot be followed in an online platform as it is time-consuming, and the students are inattentive and not motivated to perform willingly.

Constant feedback from the teachers on the students' performance is an inevitable part of students learning process. Unfortunately, giving feedback in an online classroom becomes hard for the teachers due to some constraints such as network problems, insufficient time, inattentiveness of students etc. Due to the lack of feedback from teachers, students could not get the opportunity to rectify their errors. That is why they make the same mistakes repeatedly and score low in the exams. An effective speaking class demands feedback from teachers to observe how well the students communicated individually or in groups. Students get to know their errors in grammar, pronunciation and the use of vocabulary. However, in an online speaking classroom, a teacher cannot provide his/ her valuable feedback to the students due to time constraints. As a result, students are not aware of their flaws and continue making the same mistakes repeatedly and get low marks in the exam, which lower the confidence of the students to speak fluently in the class and communicate effectively with their peers. This further lowers their motivation to learn English properly or rectify their mistakes. Therefore, the teachers have difficulty teaching speaking properly in an online classroom. In the same way, an effective writing class also needs constant feedback from teachers. In the case of creative writing, students must get the teacher's observations. In most cases, students do their writing individually. So, the teacher should give feedback individually. After finishing any piece of writing, teachers are supposed to indicate students' errors in spelling, punctuation, sentence structure, and writing style (formal/informal). So, it takes a lot of time to give feedback in writing class which seems unreal in an online classroom.

Teachers training for conducting online classes is essential in the context of Bangladesh. As they are not associated with internetbased teaching, it has been difficult for the teachers to implement new techniques to keep the students interested in a virtual class. Additionally, teachers do not know how to teach language skills in an online classroom. Due to the pandemic, they are bound to 
conduct online classes. This sudden change in the teaching model profoundly impacts their teaching. At the same time, they need to tailor a lesson plan that is suitable for online classes takes a lot of time. Moreover, teachers use the same materials for online classes that have been used for in-person classes, more or less. Besides, teachers did not develop their materials according to the need for conducting language skills in an online classroom. Hence teachers must get the proper training to conduct productive skills effectively in an online classroom.

\section{Recommendation}

1. Teachers should conduct needs analysis at the very beginning of online class; thus, they may have a glimpse of their students' need for learning productive skills. They need to revise the curriculum to meet students' needs and help them adapt to the entire process of online learning.

2. Duration for speaking and writing class should be increased. So, the students have sufficient time for speaking and writing, and teachers can provide feedback to them and make the class more fruitful.

3. The teachers have to bring constant variation in classroom activities and update the materials they are using in the class. It will help keep students motivated and encourage them to respond in an online class.

4. Teachers have to give the students sufficient exposure to the real-life situation while teaching language skills.

5. The number of students in the speaking and writing classroom should be kept limited to focus on individual students and give feedback on their mistakes.

6. The teachers can make the best use of multimedia resources and the internet in order to show students videos of native speakers to motivate them and keep them attentive in an online speaking class.

7. The network problem should be solved. As online class totally depends on the network, the authority should ensure an uninterrupted network for conducting an online class.

8. Teachers should be trained well as they need technical knowledge for conducting an online class. At the same time, training is needed to familiarise the teachers with the implementation of new teaching methods, techniques and activities suitable for conducting an online class.

The online class is hectic for both teachers and students. The authority should keep the teachers motivated to conduct their online classes effectively. In such a crucial situation, if the teachers who are considered a facilitator of learning are anxious about online teaching, the process of teaching and learning will be hampered. So, the authority should ensure a healthy work environment.

\section{Conclusion}

Due to the outbreak of the Covid-19 pandemic, education of Bangladesh shifted from offline to an online class. As a result, the teachers had to conduct classes through zoom, Facebook live, google meet etc. This new platform of teaching and learning became a new challenge for all. The difficulties became more crucial for ELT teachers who needs to involve students continuously in classroom activities. This paper aimed at exploring the problems faced by the teachers in teaching productive skills along with the role of motivation from teachers to encourage the students in classroom participation and developing confidence. This paper tried to find out the problems the teachers face due to sudden changes in learning and teaching due to the pandemic. Therefore, it will be a guideline for the teachers who can prepare materials and modify their teaching methods and techniques according to the need of the students; the authority can come up with training sessions so that next time if such a crisis occurs, they can be fully prepared beforehand. The paper's recommendations can guide the authority and policymakers to create a new education policy that involves up-gradation of teaching and learning English skills using technology instead of only following orthodoxy method of teaching. From the data collected, it was found that teachers needed more time and training for teaching English skills in online classes. In addition, motivation and feedback from the teachers are important. Besides, the setting in an online class does not allow them to involve the students in pair or group work. Finally, the teachers have agreed that an offline class is better than an online class for teaching English productive skills as students' participation is more difficult in an online class. Analyzing the finding, the researchers have recommended that need analysis should be done before planning a course, the teachers should use updated materials and techniques to keep the students interested in the class, Teachers should continuously motivate the students and give feedback on their performance and errors so that the student's confidence would not be hampered. For the sake of keeping up with time, both online and offline learning is important. During this pandemic situation, the online class was the only alternative. However, the methods followed were the ones suitable for offline classes and the teachers were not trained. So, the barriers faced by teachers were immense. The paper has tried to find out the challenges faced and have given suggestions accordingly.

\section{References}

[1] Alsyed, H. K. (2018). Troubleshooting Prospective Problems Associated with the Implementation of Communicative Language Teaching in the EFL Context. Revista Publicando, 5(4), 380-402. ISSN 1390-9304. https://revistapublicando.org/revista/index.php/crv/article/view/1107

[2] Athirah, N., Nasir, M., \& Aziz, A.A. (2020). Implementing Student-Centered Collaborative Learning When Teaching Productive Skills in An ESL Primary Classroom. International Journal of Publication and Social Studies, 5(1), 44-54. https://www.semanticscholar.org/paper/Implementing-Student-Centered-Collaborative-when-in-NasirAziz/7cd8664af2975258c0898feb0eb77804fae615a9 
[3] Bachiri, H., \& Oifaa T. (2020). The Role of ICT in the Teaching of Productive Skills in English during COVID-19: Teachers' Perceptions and Obstacles. Linguistic Forum, Volume 2, Issue 2, 2020.

https://scholar.google.com/citations?view op=view citation\&hl=en\&user=vCQjmMkAAAAJ\&citation for view=vCQjmMkAAAAJ:0EnyYjriUF $\mathrm{MC}$

[4] Barman, B., \& Basu, B. (2013). Approaches and Methods of Language Teaching. Friend' Book Corner

[5] Brown, H. D. (1994). Principles of Language Learning and Teaching. Englewood Cliffs, NJ: Prentice-Hall, Inc

[6] Dudley- Evans, T. (2001). English for specific purposes in the Cambridge Guide to TESOL: Cambridge: Cambridge University Press.

[7] Farooqui, S. (2007). Developing speaking skills of adult learners in private universities in Bangladesh: problems and solutions. Australian Journal of Adult Learning Volume 47, Number 1, April 2007. https://eric.ed.gov/?id=EJ797591

[8] Hasan, M. K. \& Akhand M. M. (2010). Approaches to Writing in EFL/ESL Context: Balancing Product and Process in Writing Class at Tertiary Level Journal of NELTA Vol. 15 No. 1-2 December 2010. https://www.academia.edu/9094702/

[9] Hassan, N. A. A. A., (2019), Saudi EFL University Instructors' Barriers to Teaching the Speaking Skills: Causes and Solutions, Arab World English Journal (February 2019), Pp. 1- 53. https://dx.doi.org/10.24093/awej/th.222

[10] Hinkel, E. (2006). Current Perspectives on Teaching the Four Skills. TESOL Quarterly Vol. 40, No. 1 (Mar. 2006$),$ pp. 109-131 (23 pages). https://www.jstor.org/stable/40264513

[11] Islam, M. Z., Rahman, A. F. M. M., and Alam, M. K. (2019). Teaching EFL Writing At The SSC Level In Bangladesh: Challenges And Considerations. International Journal of Advanced Research (IJAR), 7(8), 855-860. https://www.academia.edu/43353656/Teaching_EFL_Writing_at_The_SSC_Level_in_Bangladesh_Challenges_and_Considerations

[12] Jahan, A. (2008). Teaching Speaking Skills at Tertiary Level in Bangladesh: An Empirical Investigation, Daffodil International University Journal of Business and Economics, Vol. 3, No. 1, January 2008. http://dspace.daffodilvarsity.edu.bd:8080/bitstream/handle/20.500.11948/653/Teaching\%20speaking\%20skills\%20at\%20tertiary.pdf?sequen ce $=1$ \&isAllowed $=y$

[13] Jarvis, M. (2005). The Psychology of Effective Learning. Cheltenham: Nelson Thornes.

[14] McDonough, J. and C. Shaw. (1993). Materials and Methods in ELT: A Teacher's Guide. Blackwell: Massachusetts, USA, 152,154

[15] Nunan, D. (1989). Designing Tasks for the Communicative Classroom. Cambridge: Cambridge University Press, 32.

[16] Nunan, D. (1991). Language Teaching Methodology. New York: Prentice-Hall

[17] Rani, S. (2020). Factor Analysis: The Issues and Challenges in English Speaking Skill of Bangladeshi EFL Learners at Tertiary Level, Journal of Critical Reviews ISSN- 2394-5125 Vol 7, Issue 19, 2020.

https://www.researchgate.net/publication/344292625 Journal of Critical Reviews Factor Analysis the Issues and Challenges in English Spea king Skill of Bangladeshi EFL Learners at Tertiary Level

[18] Richards, J. C. and Rodgers, T. S. (2001). Approaches and Methods in Language Teaching. Second Edition. Cambridge: Cambridge University Press, 161

[19] Seraj, P. M. I., \& Hasan, M. K. (2020). Investigating EFL Learners' Readiness of Using Smartphone and Problems for Learning Oral English Communication Skills at Tertiary Level in an EFL Context. International Journals of Interactive Mobile Technology, ilM- Vol. 14, No. 14. https://online journals.org/index.php/i-jim/article/view/14759

[20] Siddique, S. (2015). Teaching Writing Skill Effectively in Mixed ability Classes: An Investigation of Tertiary Level Students. DIU Journal of Humanities and Social Science, Volume 3 July 2015.https://www.academia.edu/49575258/Teaching_Writing_Skill_Effectively_in_Mixed_Ability_Classes_an_Investigation_of_Tertiary_Level_Stu dents

[21] Sukirlan, M. (2014). Teaching Communication Strategies in an EFL Class of Tertiary Level. Theory and Practice in Language Studies, Vol. 4, No. 10, pp. 2033-2041, October 2014 ISSN 1799-2591. https://www.semanticscholar.org/paper/Teaching-Communication Strategies-in-an-EFLClass Sukirlan/364dc6b24396fa683189bddc4ffcdac4c995ce7b.

[22] Tangpermpoon, T. (2008). Intergraded approaches to improve students' writing skills for major English students. ABAC Journal, Vol. 28, 1-9

[23] Ur, P. (1991). A Course in Language Teaching: Practice and Theory. Cambridge: Cambridge University Press, 121.

[24] Widdowson, H. G. (1978). Teaching Language and Communication. Oxford: Oxford University Press, 58.

[25] Yousuf, M. A., (2018). Teaching EFL Speaking at The Tertiary Level: A Study in Bangladesh Context. Journal of ELT and Education (JEE), 1(1), December-2018, Page: 91-100.

https://www.academia.edu/42663013/Teaching_EFL_Speaking_At_The_Tertiary_Level_A_Study_in_Bangladesh_Context 